\title{
Paraganglioma of maxillary sinus associated with Addison's disease mimicking a vascular tumour: A case report
}

\author{
Sami A Alkindy* \\ College of Medicine, Taif university, Saudi Arabia
}

Received: July 17, 2016

Accepted: Sepember 8, 2016

Online Published: Sepember 13, 2016

DOI: $10.5430 /$ jst.v7n1p7

URL: http://dx.doi.org/10.5430/jst.v7n1p7

\begin{abstract}
Paraganglioma of the nasal and paranasal sinuses are quite rare neuroendocrine tumours, usually hormonally inactive, presenting as nasal polyps with or without epistaxis. We present a rare case of a 23-year old male, with Addison's disease, who was referred from endocrinology department with a complaint of right nasal blockage associated with recurrent epistaxis. A provisional clinical diagnosis of vascular tumour was made, computed tomography (CT) and magnetic resonant imaging (MRI) suggested hemangioma/inverted papilloma. However, biopsy reported a highly vascular tissue mimicking angiofibroma, further immunostaining studies with Synaptophysin and S-100 confirmed the diagnosis of paraganglioma. This rare tumour in the paranasal sinuses may mimic vascular tumour and can only be confirmed with histopathological immunostains studies. According to our knowledge, this is first case reported to be associated with Addison's disease in the English literature.
\end{abstract}

Key Words: Sinunasal paraganglioma, Management, Chemodectoma, Addison's disease, Cushing's syndrome

\section{INTRODUCTION}

Paraganglioma are slow growing tumours of autonomous nervous system and account for $0.5 \%$ of all head and neck tumours, they commonly arise from carotid body, jugular bulb and vagal and rarely from other regions including sinonasal, orbit, larynx. ${ }^{[1]}$ Originating from the neural crest, these vascular tumors may be hormonally active producing adrenocorticotropic hormone (ACTH), parathyroid-related peptide, antidiuretic hormone, intestinal vasoactive peptide or growth hormone, manifesting clinically as Cushing's syndrome, hypercalcemia, inappropriate secretion of antidiuretic hormone syndrome or acromegaly respectively, depending on their neurosecretory granules content. ${ }^{[2]}$

The reported sinonasal paraganglioma are $<5 \%$ of all head This variability, however, creates a challenge for both treating Arabia.

*Correspondence: Sami A Alkindy, Associate Professor; Email: samikindy@ hotmail.com; Address: College of Medicine, Taif university, Saudi 
physician and histopathologists alike, especially if there is an association with systemic disease, i.e. Cushing's syndrome or Addison's disease, as seen in our case.

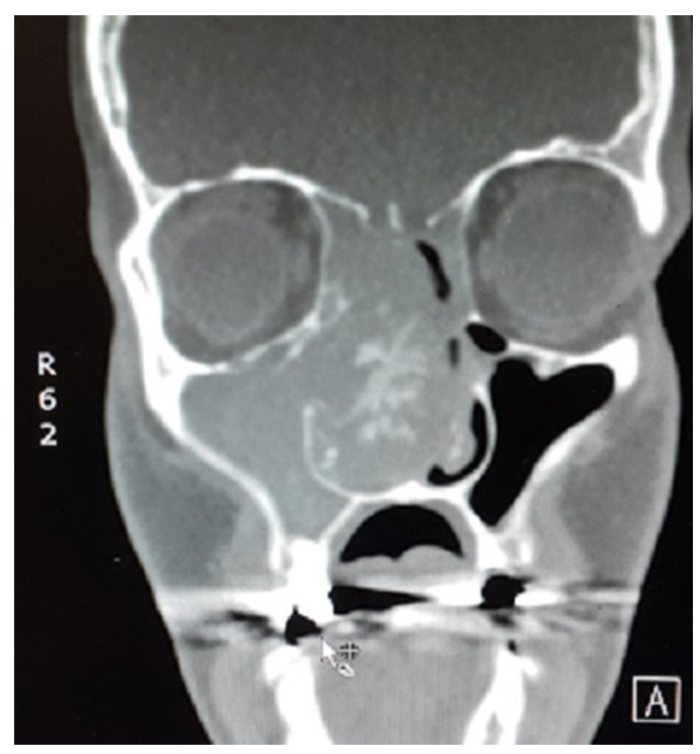

Figure 1. Coronal CT Scan demonstrating a homogenous mass of right maxillary sinus with scalloping of septum

\section{CaSe presentation}

A 23-year old male known case of Addison's disease on fludrocortisone referred to our Otorhinolaryngology outpatient department with a complaint of chronic right nasal blockage and recurrent epistaxis. He had multiple hospital admission related to the primary disease.

On presentation laboratory report was: Hemoglobin $12 \mathrm{gm} / \mathrm{L}$, White cell count 2.24, Platelet 224/. $\mathrm{mm}^{3}$, Na $133 \mathrm{mmol} / \mathrm{L}$ and K $5.1 \mathrm{mmol} / \mathrm{L}$. And Blood pressure 120/70 and pulse $80 / \mathrm{min}$. Nasal endoscopic examination showed a large polyp in the right nasal cavity which was not actively bleeding. Considering his general condition, the option of a biopsy under local anaesthetic was taken, which was followed by copious bleeding that was controlled by nasal packing.

CT of the paranasal sinuses revealed a homogenous mass occupying right maxillary sinus extending to the right nasal cavity with scalloping of septum, with no evidence of bony erosion (see Figure 1), and MRI showed a hypertense on fluidattenuated inversion recovery (FLAIR) and T2W1, while it was hypotense on T1 (see Figure 2) with diffuse enhancement in T1W1- Post contrast. The differential diagnosis included, vascular tumour/inverted Papilloma.

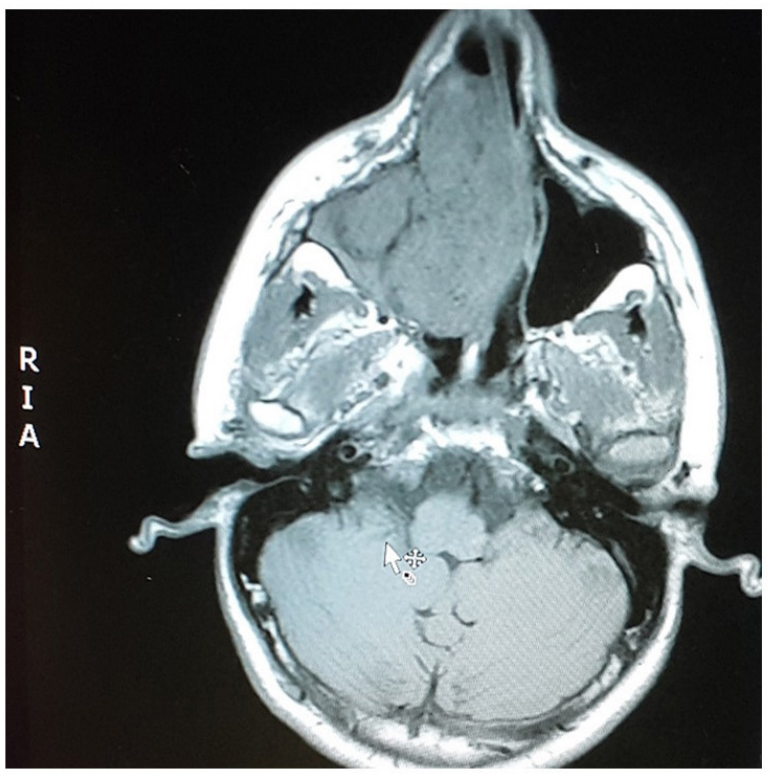

A

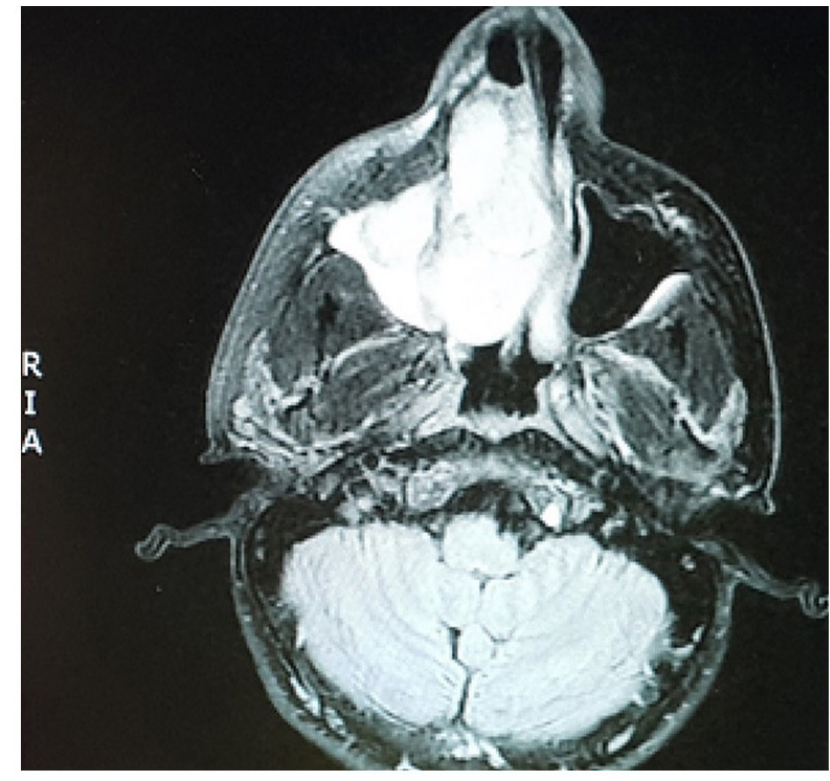

B

Figure 2. A) MRI T1 Demonstrating hypotense mass in right maxillary sinus; B) MRI demonstrating diffuse enhancement with $\mathrm{T} 2 \mathrm{~W} 1$ post contrast

The initial histopathology reported a highly vascular tissue mimicking angiofibroma, however, further studies with neuron specific enolase (NSE), CD56, synaptophysin and S-100 stain showed sustentacular cells (nerve twigs) confirmed the diagnosis of paraganglioma (see Figure 3).

Surgical option was offered to the patient, however, he opted to be treated elsewhere. 


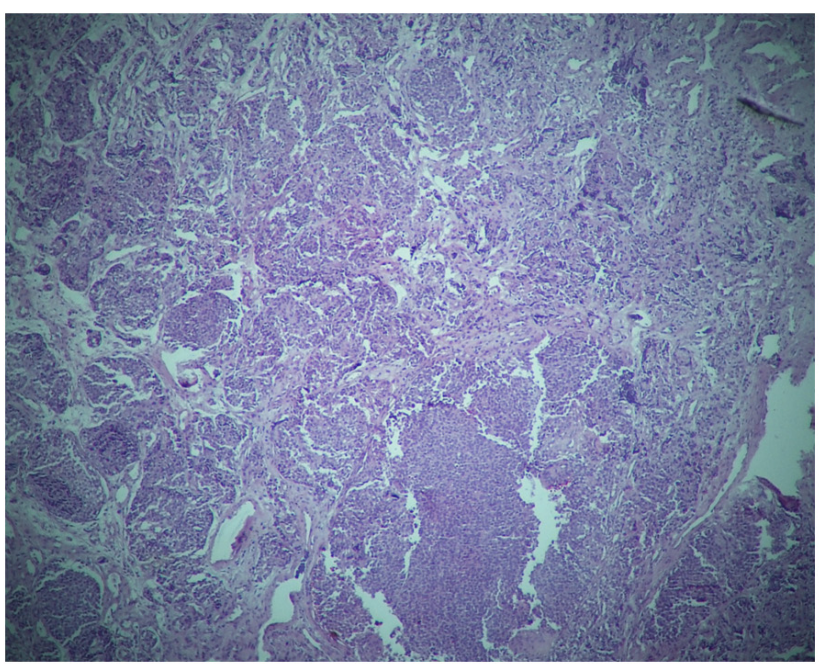

A

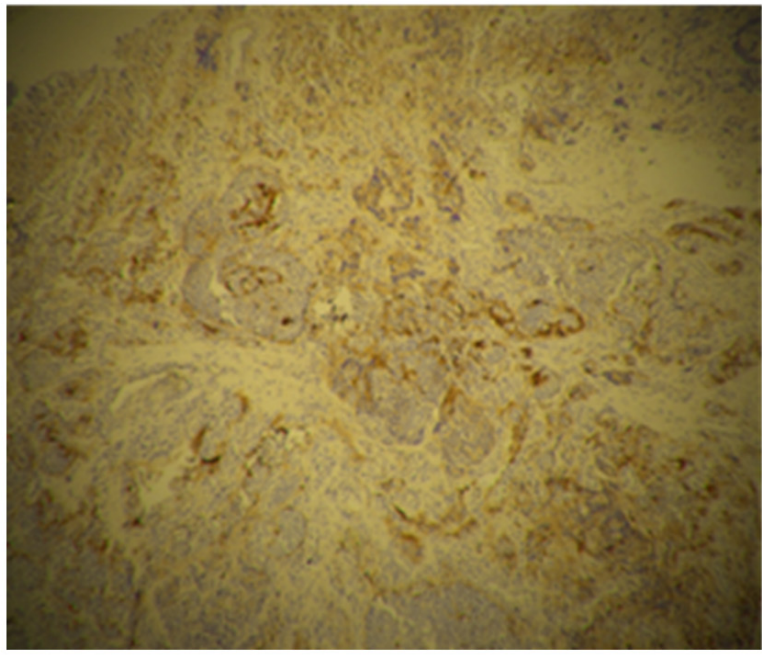

$\mathrm{B}$

Figure 3. A) Classical Zellbellan cell nests; B) S-100 stains highlighting sustentacular cells (nerve twigs)

\section{Discussion}

The clinicopathology of sinonasal paraganglioma in comparison to other head and neck paraganglioma are not quite well understood, arising from middle turbinate, fronto-ethmoid air cells, ${ }^{[4]}$ sphenoid ${ }^{[12]}$ and maxillary sinus, ${ }^{[13]}$ skull base $^{[5]}$ and pterygopalatine fissure, ${ }^{[10]}$ they are rarely hormonally active with only three reported cases, ${ }^{[8,9]}$ moreover they have no named related Paraganglions.

Although these tumors are mainly benign, aggressive malignant clinical behavior with metastasis was noted in some cases where their morphology showed no features of mitosis. ${ }^{[14]}$ This, however, was not shared by others. ${ }^{[15]}$

Furthermore, radiotherapy that is used as a mode of treatment has been implicated in its malignant transformation. ${ }^{[1]}$

Diagnostic challenges arises when clinical features as well as imaging modules including CT, MRI and PET are nonspecific, ${ }^{[6]}$ and the typical morphology findings mentioned above are atypical, i.e. lipoblast-like vacuolated cells. ${ }^{[14]}$

Our pathology department used Immuno-Histo-Chemistry (IHC) Ventana detection system benchmark XT: In which CD56, Synaptophysin and Neuron Specific Enolase (NSA) were positive while Alpha Smooth Muscle Actin Antibody (ASMA) highlighted a dense vascularity particularly of the lesion area. This might explain the initial pathologist's findings.

The association of sinonasal paraganglioma with Addison's disease, an autoimmune condition, seen in our case and not previously reported, is probably un-related. Whereas, its association with Cushing's syndrome ${ }^{[7]}$ and $\operatorname{AIDS}^{[17]}$ in other reports, can be explained by the ectopic hormonal affect and blood transfusion respectively.

In conclusion, sinonasal paraganglioma, indeed is a rare entity, and has variable presentations, little is known about its Pathiophysiology. Its diagnosis remains to be a challenge, listing it among the differential diagnosis may help future management plan strategies.

\section{ACKNOWLEDGEMENTS}

I would like to thank Dr. A. Mastan for his valuable contribution.

\section{CONFlicts of InTEREST Disclosure}

The authors declare that there is no conflict of interest statement.

\section{REFERENCES}

[1] Sharma HS, Madhavan M, Othman NH, et al. Malignant Paraganglioma of frontoethmoidal region. Auris Nasus Larynx. 1999 Oct; 26(4): 487-93. http://dx.doi.org/10.1016/S0385-8146 (99 ) 00030-9

[2] William F, Young Jr. Endocrine hypertension. In Williams Textbook of Endocrinology, edn 11. 2011: 427-34.
[3] Lack EE, Cubilla AL, Woodruff JM. Paragangliomas of the head and neck region. A pathologic study of tumors from 71 patients. Hum Pathol. 1979 Mar; 10(2): 191-218. http://dx.doi.org/10.1016 /S0046-8177 (79)80008-8

[4] Mevio E, Bignami M, Luinetti O, et al. Nasal Paraganglioma. A case report. Acta Otorhinolaryngol Belg. 2001; 55: 247-9. PMid:11685963. 
[5] Amiraraghi N, Syed MI, Syed S, et al. Paraganglioma of the skull base presenting as nasal polyps. Laryngoscope. 2013 Mar; 123(3): 577-80. PMid:23027682. http://dx.doi.org/10.1002/lary . 23645

[6] Ueda N, Yoshida A, Fukunishi R, et al. Nonchromaffin Paraganglioma in the nose and paranasal sinuses. Acta Pathol Jpn. 1985 Mar; 35(2): 489-95. http://dx.doi.org/10.1111/j.1440-1 827.1985.tb00591.x

[7] Lieberum B, Jaspers C, Münzenmaier R. ACTH-producing Paraganglioma of the paranasal sinuses. HNO. 2003 Apr; 51(4): 328-31 PMid:12682736.

[8] Apple D, Kreines K. Cushing's syndrome due to ectopic ACT production by a nasal paraganglioma. American Journal of the Medical Sciences. 1982; 283: 32-5. PMid:6275703. http://dx.doi.org /10.1097/00000441-198201000-00005

[9] Liebernun B, Jaspers C, Munzenmaier R. ACTH producing paraganglioma of the nasal parasinuses. HNO. 2003; 51: 328 31. PMid:12682736. http://dx.doi.org/10.1007/s00106-0 02-0695-8

[10] Rabbia C, Liboni W, Pia F, et al. Chemodectoma of the pterygomaxillary fossa. Minerva Med. 1983 Dec 15; 74(47-48): 2815-9. PMid:6318160.

[11] Aydın S, Karabulut B, Orhan KS, et al. A case of sinonasal Paraganglioma with a different morphology: nine-year follow-up. $\mathrm{Ku}$ - lak Burun Bogaz Ihtis Derg. 2015; 25(1): 43-5. PMid:25934406. http://dx.doi.org/10.5606/kbbihtisas. 2015.04568

[12] Morales H, Castillo M, Jewells V. Paraganglioma of the sphenoid sinus: case report and review of literature. Clin Imaging. $2007 \mathrm{Jan}-$ Feb; 31(1): 32-6. PMid:17189844. http://dx . doi .org/10.1016 /j.clinimag.2006.10.001

[13] Kisser U, Braun T, Mayr D, et al. Paraganglioma of the maxillary sinus. Auris Nasus Larynx. 2013 Oct; 40(5): 506-9. Epub 2012 Dec 21. PMid:23265579. http://dx.doi.org/10.1016/j.anl. 201 2.10 .009

[14] Papaspyrou K, Welkoborsky HJ, Gouveris H, et al. Malignant and benign sinonasal paragangliomas. Laryngoscope. 2013 Aug; 123(8): 1830-6. Epub 2013 Jan 31. PMid:23371358. http: //dx. doi .org /10.1002/lary. 23985

[15] Sarin H, Nigam S, Chaturvedi UK, et al. Malignant nasal Paraganglioma: a case report and review of the literature. Indian J Pathol Microbiol. 2003 Jan; 46(1): 97-9. PMid:15027743.

[16] Apple D, Kreines K. Cushing's syndrome due to ectopic ACTH production by a nasal Paraganglioma. Am J Med Sci. 1982 Jan-Feb; 283(1): 32-5. PMid:6275703. http://dx.doi.org/10.1097/0 0000441-198201000-00005

[17] Fasunla AJ, Ibekwe TS, Afolabi OA, et al. Sinonasal Paraganglioma: a case report. Oral Maxillofac Surg. 2008 Jul; 12(2): 936. PMid:18581152. http://dx.doi.org/10.1007/s10006-008 $-0104-x$ 